\title{
Front Matter: Volume 7527
}

, "Front Matter: Volume 7527," Proc. SPIE 7527, Human Vision and Electronic Imaging XV, 752701 (1 March 2010); doi: 10.1117/12.858948

SPIE Event: IS\&T/SPIE Electronic Imaging, 2010, San Jose, California, United SPIE. States 


\section{PROCEEDINGS \\ IS\&T / SPIE \\ Electronic \\ Imaging \\ SCIENCE AND TECHNOLOGY}

\section{Human Vision and Electronic Imaging $X V$}

Bernice E. Rogowitz

Thrasyvoulos N. Pappas

Editors

18-21 January 2010

San Jose, California, United States

Sponsored and Published by

IS\&T-The Society for Imaging Science and Technology

SPIE

Cosponsored by

Aptina Imaging Corporation (United States) 
The papers included in this volume were part of the technical conference cited on the cover and title page. Papers were selected and subject to review by the editors and conference program committee. Some conference presentations may not be available for publication. The papers published in these proceedings reflect the work and thoughts of the authors and are published herein as submitted. The publishers are not responsible for the validity of the information or for any outcomes resulting from reliance thereon.

Please use the following format to cite material from this book:

Author(s), "Title of Paper," in Human Vision and Electronic Imaging XV, edited by Bernice E. Rogowitz, Thrasyvoulos N. Pappas, Proceedings of SPIE-IS\&T Electronic Imaging, SPIE Vol. 7527, Article CID Number (2010).

ISSN 0277-786X

ISBN 9780819479204

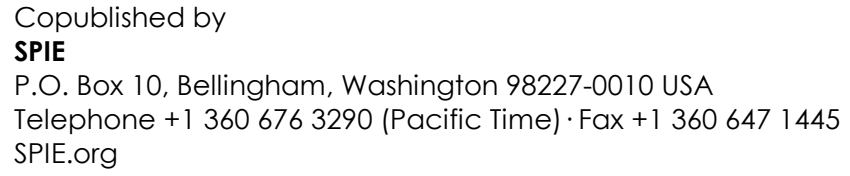

Copyright (c) 2010, Society of Photo-Optical Instrumentation Engineers and The Society for Imaging Science and Technology.

Copying of material in this book for internal or personal use, or for the internal or personal use of specific clients, beyond the fair use provisions granted by the U.S. Copyright Law is authorized by the publishers subject to payment of copying fees. The Transactional Reporting Service base fee for this volume is $\$ 18.00$ per article (or portion thereof), which should be paid directly to the Copyright Clearance Center (CCC), 222 Rosewood Drive, Danvers, MA 01923. Payment may also be made electronically through CCC Online at copyright.com. Other copying for republication, resale, advertising or promotion, or any form of systematic or multiple reproduction of any material in this book is prohibited except with permission in writing from the publisher. The CCC fee code is $0277-786 \mathrm{X} / 10 / \$ 18.00$.

Printed in the United States of America.

Paper Numbering: Proceedings of SPIE follow an e-First publication model, with papers published first online and then in print and on CD-ROM. Papers are published as they are submitted and meet publication criteria. A unique, consistent, permanent citation identifier (CID) number is assigned to each article at the time of the first publication. Utilization of CIDs allows articles to be fully citable as soon they are published online, and connects the same identifier to all online, print, and electronic versions of the publication. SPIE uses a six-digit CID article numbering system in which:

- The first four digits correspond to the SPIE volume number.

- The last two digits indicate publication order within the volume using a Base 36 numbering system employing both numerals and letters. These two-number sets start with 00, 01, 02, 03, 04, 05 , 06, 07, 08, 09, OA, OB ... 0Z, followed by 10-1Z, 20-2Z, etc.

The CID number appears on each page of the manuscript. The complete citation is used on the first page, and an abbreviated version on subsequent pages. Numbers in the index correspond to the last two digits of the six-digit CID number. 


\section{Contents}

ix Conference Committee

xi Photographing the range of light: works by Ansel Adams and John Sexton (Keynote Paper) J. Sexton, John Sexton Photography (United States)

KEYNOTE SESSION

752703 Music in film and animation: experimental semiotics applied to visual, sound, and musical structures (Keynote Paper) [7527-02]

R. A. Kendall, Univ. of California, Los Angeles (United States)

\section{ARTIFICIAL RETINA}

752705

In vivo operation of the Boston 15-channel wireless subretinal visual prosthesis [7527-04] D. B. Shire, Cornell Univ. (United States) and VA Ctr. for Innovative Visual Rehabilitation (United States); P. Doyle, S. K. Kelly, VA Ctr. for Innovative Visual Rehabilitation (United States) and Massachusetts Institute of Technology (United States); M. D. Gingerich, Cornell Univ. (United States) and VA Ctr. for Innovative Visual Rehabilitation (United States); J. Chen, Massachusetts Eye and Ear Infirmary (United States); S. F. Cogan, ElC Labs., Inc. (United States); W. A. Drohan, VA Ctr. for Innovative Visual Rehabilitation (United States) and Massachusetts Institute of Technology (United States); O. Mendoza, Massachusetts Institute of Technology (United States); L. Theogarajan, Univ. of California, Santa Barbara (United States); J. Wyatt, Massachusetts Institute of Technology (United States); J. F. Rizzo, VA Ctr. for Innovative Visual Rehabilitation (United States) and Massachusetts Eye and Ear Infirmary (United States)

\section{ADVANCED BRAIN IMAGING, PERCEPTION, AND COGNITION}

752707 Human brain imaging during controlled and natural viewing [7527-07]

S. A. Klein, T. Carney, D. Kim, Univ. of California, Berkeley (United States); S. Dandekar, New York Univ. (United States); C. Privitera, Univ. of California, Berkeley (United States)

752708 Drawing in the blind and the sighted as a probe of cortical reorganization [7527-08]

L. T. Likova, The Smith-Kettlewell Eye Research Institute (United States)

752709 Advances in electromagnetic brain imaging [7527-09]

S. S. Nagarajan, Univ. of California, San Francisco (United States)

7527 OA Top-down modulation: the crossroads of perception, attention, and memory [7527-10] A. Gazzaley, Univ. of California, San Francisco (United States)

$7527 \mathrm{OB}$ Isolating human brain functional connectivity associated with a specific cognitive process [7527-11]

M. A. Silver, A. N. Landau, T. Z. Lauritzen, W. Prinzmetal, L. C. Robertson, Univ. of California, Berkeley (United States) 
7527 OE Statistical analysis of subjective preferences for video enhancement [7527-14] R. L. Woods, P. Satgunam, P. M. Bronstad, E. Peli, Schepens Eye Research Institute (United States)

7527 OF Tradeoffs in subjective testing methods for image and video quality assessment [7527-15] D. M. Rouse, Cornell Univ. (United States); R. Pépion, P. Le Callet, Univ. de Nantes (France); S. S. Hemami, Cornell Univ. (United States)

7527 OG Calibration of the visual difference predictor for estimating visibility of JPEG2000 compression artifacts in $\mathrm{CT}$ images [7527-16]

K. J. Kim, Seoul National Univ. (Korea, Republic of); R. Mantiuk, The Univ. of British Columbia (Canada) and Bangor Univ. (United Kingdom); K. H. Lee, Seoul National Univ. (Korea, Republic of); W. Heidrich, The Univ. of British Columbia (Canada)

$7527 \mathrm{OH} \quad$ A subjective study to evaluate video quality assessment algorithms [7527-17] K. Seshadrinathan, Intel Corp. (United States); R. Soundararajan, A. C. Bovik, L. K. Cormack, The Univ. of Texas at Austin (United States)

7527 Ol Subjective assessment of HDTV content: comparison of quality across HDTV formats [7527-18]

J. Meenowa, D. S. Hands, R. Young, D. Bayart, British Telecommunications plc. (United Kingdom)

\section{NEW DIRECTIONS IN IMAGE QUALITY}

7527 0J The medium and the message: a revisionist view of image quality [7527-19]

J. A. Ferwerda, Rochester Institute of Technology (United States)

7527 OK Quantifying the relationship between visual salience and visual importance [7527-20] J. Wang, South China Univ. of Technology (China) and Univ. de Nantes (France);

D. M. Chandler, Oklahoma State Univ. (United States); P. Le Callet, Univ. de Nantes (France)

$7527 \mathrm{OL}$ Synchronization mismatch: vernier acuity and perception evaluation for large ultra high resolution tiled displays [7527-21]

S. Deshpande, S. Daly, Sharp Labs. of America (United States)

7527 OM A perceptual similarity measure based on smoothing filters and the normalized compression distance [7527-22]

N. Tran, Santa Clara Univ. (United States)

VISUAL, AUDITORY, AND TACTILE PERCEPTION

7527 ON Subband analysis and synthesis of real-world textures for objective and subjective determination of roughness [7527-23]

R. van Egmond, Delft Univ. of Technology (Netherlands); T. N. Pappas, Northwestern Univ. (United States); H. de Ridder, Delft Univ. of Technology (Netherlands) 
752700 Psychoacoustic and cognitive aspects of auditory roughness: definitions, models, and applications [7527-24]

P. N. Vassilakis, Columbia College Chicago (United States); R. A. Kendall, Univ. of California, Los Angeles (United States)

7527 OP Audio-visual interactions in product sound design [7527-62]

E. Özcan, R. van Egmond, Delft Univ. of Technology (Netherlands)

$7527 \mathrm{OQ}$ Tangible display systems: direct interfaces for computer-based studies of surface appearance [7527-26]

B. A. Darling, J. A. Ferwerda, Rochester Institute of Technology (United States)

ART AND SCIENCE RENDER THE HIGH-DYNAMIC-RANGE WORLD I

7527 OS The Ansel Adams zone system: HDR capture and range compression by chemical processing [7527-28]

J. J. McCann, McCann Imaging (United States)

7527 OT Ansel Adams: early works (Invited Paper) [7527-61]

J. Throckmorton, San Jose Museum of Art (United States)

\section{ART AND SCIENCE RENDER THE HIGH-DYNAMIC-RANGE WORLD II}

7527 OU The drama of illumination: artist's approaches to the creation of HDR in paintings and prints (Invited Paper) [7527-29]

C. Parraman, Univ. of the West of England (United Kingdom)

7527 OV Darkness and depth in early Renaissance painting [7527-30]

C. Tyler, The Smith-Kettlewell Eye Research Institute (United States)

7527 OW The luminance of pure black: exploring the effect of surround in the context of electronic displays [7527-31]

R. K. Mantiuk, Bangor Univ. (United Kingdom) and Sharp Labs. of America, Inc. (United

States); S. Daly, L. Kerofsky, Sharp Labs. of America, Inc. (United States)

7527 OX Object size, spatial-frequency content and retinal contrast [7527-32]

A. Rizzi, Univ. degli Studi di Milano (Italy)

7527 OY The effect of exposure on MaxRGB color constancy [7527-33]

B. Funt, L. Shi, Simon Fraser Univ. (Canada)

$7527 \mathrm{OZ}$ Gloss discrimination and eye movements [7527-34]

J. B. Phillips, J. A. Ferwerda, A. Nunziata, Rochester Institute of Technology (United States)

752710 Visual maladaptation in contrast domain [7527-35]

D. Pająk, Westpomeranian Univ. of Technology (Germany) and Max-Planck-Institut für Informatik (Germany); M. Čadík, T. O. Aydin, K. Myszkowski, H.-P. Seidel, Max-Planck-Institut für Informatik (Germany) 
752712 Synthetic environments as visualization method for product design [7527-37]

F. Meijer, Univ. Twente (Netherlands); E. L. van den Broek, Univ. Twente (Netherlands), Human-Centered Computing Consultancy (Austria), and Radboud Univ. Medical Ctr. Nijmegen (Netherlands); T. E. Schouten, Radboud Univ. Nijmegen (Netherlands); R. G. J. Damgrave, Univ. Twente (Netherlands); H. de Ridder, Technische Univ. Delft (Netherlands)

\section{COGNITION, ATTENTION, AND EYE MOVEMENTS IN IMAGE ANALYSIS}

752714 Interest of perceptive vision for document structure analysis [7527-39]

A. Lemaitre, Univ. de Rennes 2 (France); J. Camillerapp, B. Coüasnon, INSA de Rennes

(France) and Univ. Européenne de Bretagne (France)

752715 Visual recognition of permuted words [7527-40]

S. F. Rashid, Technical Univ. of Kaiserslautern (Germany); F. Shafait, German Research Ctr. for Artificial Intelligence (Germany); T. M. Brevel, Technical Univ. of Kaiserslautern (Germany) and German Research Ctr. for Artificial Intelligence (Germany)

752717 Effects of stimulus size and velocity on steady-state smooth pursuit induced by realistic images [7527-42]

F. Li, Aptina Imaging Corp. (United States); J. B. Pelz, Rochester Institute of Technology (United States); S. J. Daly, Sharp Labs. of America, Inc. (United States)

\section{ART, AESTHETICS, AND PERCEPTION}

752718 Human preference for individual colors (Keynote Paper) [7527-43]

S. E. Palmer, K. B. Schloss, Univ. of California, Berkeley (United States)

752719 Aesthetics of color combinations [7527-44]

K. B. Schloss, S. E. Palmer, Univ. of California, Berkeley (United States)

7527 1A Preference for art: similarity, statistics, and selling price [7527-45]

D. J. Graham, Dartmouth College (United States); J. D. Friedenberg, Manhattan College (United States); C. H. McCandless, Merchant Mechanics, Inc. (United States);

D. N. Rockmore, Dartmouth College (United States)

7527 1B The death of the object: perceiving non-physical art [7527-47]

L. Markopoulos, California College of the Arts (United States)

7527 1C Rendering nothingness: reality and aesthetics in Haboku landscape for understanding cognition and computer interfaces [7527-48]

H. K. Rising III, Consultant (United States)

7527 ID How did Leonardo perceive himself? Metric iconography of da Vinci's self-portraits [7527-49]

C. W. Tyler, The Smith-Kettlewell Eye Research Institute (United States) 
7527 IF No-reference image quality assessment based on localized gradient statistics: application to JPEG and JPEG2000 [7527-52]

H. Liu, Delft Univ. of Technology (Netherlands); J. Redi, Univ. of Genoa (Italy); H. Alers, Delft Univ. of Technology (Netherlands); R. Zunino, Univ. of Genoa (Italy); I. Heynderickx, Delft Univ. of Technology (Netherlands) and Philips Research Labs. (Netherlands)

7527 IG Automated videography for residential communications [7527-53]

A. F. Kurtz, C. Neustaedter, A. C. Blose, Eastman Kodak Co. (United States)

$752711 \quad$ Efficient motion weighted spatio-temporal video SSIM index [7527-55]

A. K. Moorthy, A. C. Bovik, The Univ. of Texas at Austin (United States)

7527 1 J The impact of transmission errors on progressive 720 lines HDTV coded with H.264 [7527-56] K. Brunnström, D. Stålenbring, Acreo AB (Sweden); M. Pettersson, J. Gustafsson, Ericsson Research (Sweden)

7527 IK Divisive normalization in channelized Hotelling observer [7527-57]

T. Luo, X. Mou, Xi'an Jiaotong Univ. (China)

$7527 \mathrm{IL} \quad$ Perceptual quality assessment of color images using adaptive signal representation [7527-58]

U. Rajashekar, New York Univ. (United States); Z. Wang, Univ. of Waterloo (Canada);

E. P. Simoncelli, New York Univ. (United States)

7527 iN Study of recognizing multiple persons' complicated hand gestures from the video sequence acquired by a moving camera [7527-60]

L. Dan, J. Ohya, Waseda Univ. (Japan)

Author Index 
Downloaded From: https://www.spiedigitallibrary.org/conference-proceedings-of-spie on 26 Apr 2023

Terms of Use: https://www.spiedigitallibrary.org/terms-of-use 


\title{
Conference Committee
}

\author{
Symposium Chair
}

Jan P. Allebach, Purdue University (United States)

Symposium Cochair

Sabine Süsstrunk, Ecole Polytechnique Fédérale de Lausanne (Switzerland)

Conference Chairs

Bernice E. Rogowitz, Visual Perspectives Consulting (United States) Thrasyvoulos N. Pappas, Northwestern University (United States)

\section{Program Committee}

Albert J. Ahumada, NASA Ames Research Center (United States) Jan P. Allebach, Purdue University (United States)

Erhardt Barth, Universität zu Lübeck (Germany)

Walter R. Bender, MIT Media Laboratory (United States)

Michael H. Brill, Datacolor (United States)

John C. Dalton, Synthetik Software (United States)

Scott J. Daly, Sharp Laboratories of America, Inc. (United States)

Huib de Ridder, Technische Universiteit Delft (Netherlands)

Elena A. Fedorovskaya, Eastman Kodak Company (United States)

Jennifer Gille, Qualcomm Inc. (United States)

Sheila S. Hemami, Cornell University (United States)

Laurent Itti, University of Southern California (United States)

Stanley A. Klein, University of California, Berkeley (United States)

Patrick Le Callet, Université de Nantes (France)

John J. McCann, McCann Imaging (United States)

Jeffrey B. Mulligan, NASA Ames Research Center (United States)

Karol Myszkowski, Max-Planck-Institut für Informatik (Germany)

Adar Pelah, The University of York (United Kingdom)

Eliezer Peli, Schepens Eye Research Institute (United States)

Hawley K. Rising III, Consultant (United States)

Sabine Süsstrunk, Ecole Polytechnique Fédérale de Lausanne (Switzerland)

Chirstopher W. Tyler, The Smith-Kettlewell Eye Research Institute (United States)

Andrew B. Watson, NASA Ames Research Center (United States) 
Session Chairs

1 Keynote Session

Bernice E. Rogowitz, Visual Perspectives Consulting (United States)

Thrasyvoulos N. Pappas, Northwestern University (United States)

2 Artificial Retina

Melville R. V. Sahyun, Consultant (United States)

3 Advanced Brain Imaging, Perception, and Cognition

Lora T. Likova, The Smith-Kettlewell Eye Research Institute (United States)

Stanley A. Klein, University of California, Berkeley (United States)

4 Advances in Image Quality

Eliezer Peli, Schepens Eye Research Institute (United States)

5 New Directions in Image Quality

Bernice E. Rogowitz, Visual Perspectives Consulting (United States)

6 Visual, Auditory, and Tactile Perception

Thrasyvoulos N. Pappas, Northwestern University (United States)

$7 \quad$ Art and Science Render the High-Dynamic-Range World I

John J. McCann, McCann Imaging (United States)

8 Art and Science Render the High-Dynamic-Range World II John J. McCann, McCann Imaging (United States)

9 Perceptual and Cognitive Experiments in Virtual Environments Jeffrey B. Mulligan, NASA Ames Research Center (United States)

10 Cognition, Attention, and Eye Movements in Image Analysis Jeffrey B. Mulligan, NASA Ames Research Center (United States)

11 Art, Aesthetics, and Perception

Christopher W. Tyler, The Smith-Kettlewell Eye Research Institute (United States)

Hawley K. Rising III, Consultant (United States) 


\title{
Photographing the range of light: Works by Ansel Adams and John Sexton
}

\author{
John Sexton* \\ John Sexton Photography (United States);
}

\begin{abstract}
In 1979, Ansel Adams published a collection of his photographs titled "Yosemite and the Range of Light."[1] Ansel, more than many photographers, realized that light falling on a scene is both a challenge, as well as a creative opportunity. The challenge being that one-size-fits-all automation of scene capture cannot handle the great changes in light intensity. Creative opportunities, with variations from deep shade with uniform illumination to strong direct sun and dark shadows, can make photographs more interesting and compelling. During my many years working closely with Ansel, I realized that the true subject matter of a successful photograph is indeed light. Ansel codified the techniques of capturing and rendering the natural scene with his Zone System of exposure and development. The key element of Adams' Zone System is the ability to visualize within the limits of the photographic materials. This talk will illustrate through Adams' photographs, and my own images, the importance of interpreting - rather than mere recording - in creative photography. It will include examples of photographs before and after the resourceful steps involved in expressive printmaking, which create an image that not only is a representation of what we see, but also what we feel.
\end{abstract}

Keywords: photography, zone system, rendering the natural image

\section{AN ANNOTATED BIBLIOGRAPHY}

Using photographs by Ansel Adams and the author, this talk describes the capture and rendition of the natural scene.

The images used in this talk can be found in a series of books:

Ansel Adams,

“The Eloquent Light", 1963 [2]

"Photographs of the Southwest" 1976 [3]

“The Portfolios of Ansel Adams", 1977 [4]

"Yosemite and the Range of Light", 1979 [1]

Ansel wrote a series of technical manuals that described the details of the Zone System.

Ansel Adams,

"The Camera: The New Ansel Adams Photography Series/Book One", 1980 [5]

"The Negative: The New Ansel Adams Photography Series/Book Two", 1981 [6]

"The Print: The New Ansel Adams Photography Series/Book Three," 1983 [7]

"Natural Light Photography: Basic Photo Four", 1956 [8]

"Artificial Light Photography: Basic Photo Five" [9]

"Polaroid Land Photography”, 1978 [10] 
Ansel described the circumstances and techniques he used in making his most celebrated images:

Ansel Adams,

“Ansel Adams: Letters and Images, 1916-1984", (1988) [11]

"Examples: The Making of 40 Photographs", (1989). [12]

Ansel's biography, written with Mary Alinder provides different insights into Ansel's works:

“Ansel Adams: An Autobiography", (1996) [13]

The images by the author can be found in the following books:

John Sexton,

"Quiet Light", (1990) [14]

"Listen to the Trees", (1994) [15]

"Places of Power: The Aesthetics of Technology", (2000) [16]

"Recollections: Three Decades of Photographs", (2006) [17]

\section{REFERENCES}

*john@johnsexton.com

[1] Adams, A., [Yosemite and the Range of Light], Little Brown, Boston, (1979).

[2] Adams, A., [The Eloquent Light], Sierra Club, San Francisco, (1963).

[3] Adams, A., [Photographs of the Southwest], New York Graphic Society, Boston, (1976).

[4] Adams, A., [The Portfolios of Ansel Adams], New York Graphic Society, Boston, (1977).

[5] Adams, A., [The Camera: The New Ansel Adams Photography Series/Book One], New York Graphic Society, Boston, (1980).

[6] Adams, A., [The Negative: The New Ansel Adams Photography Series/Book Two], New York Graphic Society, Boston, (1981).

[7] Adams, A., [The Print: The New Ansel Adams Photography Series/Book Three], New York Graphic Society, Boston, (1983).

[8] Adams, A., [Natural Light Photography: Basic Photo Four], New York Graphic Society, Boston, (1952).

[9] Adams, A., [Artificial Light Photography: Basic Photo Five], New York Graphic Society, Boston, (1956).

[10] Adams, A., [Polaroid Land Photography], New York Graphic Society, Boston, (1978).

[11] Adams, A., [Ansel Adams: Letters and Images, 1916-1984] Little Brown, Boston, (1988).

[12] Adams, A., [Examples: The Making of 40 Photographs] Little Brown, Boston, (1989).

[13] Adams, A, and Alinder, M. S., [Ansel Adams : An Autobiography], Little Brown, Boston, (1996).

[14] Sexton, J., [Quiet Light], Little Brown, Boston, (1990).

[15] Sexton, J., [Listen to the Trees], Little Brown, Boston, (1994).

[16] Sexton, J., [Places of Power: The Aesthetics of Technology], Ventana Editions, Carmel Valley, California, (2000).

[17] Sexton, J., [Recollections: Three Decades of Photographs], Ventana Editions, Carmel Valley, California, (2006). 